\title{
KOMODITAS PERIKANAN UNGGULAN KABUPATEN PATI DALAM SKALA PROVINSI JAWA TENGAH
}

\section{LEADING FISHERY COMMODITIES OF PATI REGENCY IN CENTRAL JAVA PROVINCE SCALE}

\author{
Herna Octivia Damayanti \\ Kantor Penelitian dan Pengembangan Kabupaten Pati \\ E-mail: octivia_oc@yahoo.co.id
}

Naskah Masuk: 14 Mei 2014

Naskah Revisi: 21 Mei 2014

Naskah Diterima: 26 Mei 2014

\begin{abstract}
The leading of Fishery commodities in Pati Regency are aquaculture pond fishery and marine capture fishery. Objectives of the research are (1) to describe the development of Pati Regency leading commodities in 2008-2012; (2) to describe the contribution of Pati Regency leading commodities to Central Java Province; and (3) to describe Pati Regency leading commodities position in Central Java Province scale. The research used descriptive method and was held in December 2013. Secondary data source namely marine capture fishery and aquaculture pond fishery production data from Statistics of Central Java Province for 2008, 2009, 2010, 2011 and 2012. Data was analyzed descriptively. The results were: (1) Both capture fishery and aquaculture pond fishery during the last 5 years (2008-2012) showed positive trend, that increased constantly; (2) the percentage of aquaculture pond fishery contribution is above 20\% (range 23-28\%), meanwhile marine capture fishery below 20\% (range 15-18\%); (3) Pati Regency marine capture fishery in 2008 and 2009 was ranked third, but three years later namely 2010, 2011 and 2012 managed to rank second in the Central Java Province scale. While, Pati Regency aquaculture pond fishery was ranked second in the last 5 years.
\end{abstract}

Keywords: leading commodity, aquaculture pond fishery, marine capture fishery

\begin{abstract}
ABSTRAK
Hasil perikanan yang menjadi komoditas unggulan di Kabupaten Pati adalah komoditas perikanan budidaya tambak dan perikanan laut tangkap. Tujuan penelitian adalah (1) menggambarkan perkembangan hasil komoditas perikanan unggulan Kabupaten Pati tahun 2008-2012; (2) menggambarkan besaran kontribusi komoditas perikanan unggulan Kabupaten Pati kepada Provinsi Jawa Tengah; dan (3) menggambarkan posisi komoditas perikanan unggulan Kabupaten Pati dalam skala Provinsi Jawa Tengah. Penelitian menggunakan metode deskriptif dan dilaksanakan bulan Desember 2013. Sumber data sekunder yaitu data produksi perikanan laut tangkap dan perikanan budidaya tambak dari Badan Pusat Statistik Provinsi Jawa Tengah untuk tahun 2008, 2009, 2010, 2011 dan 2012. Analisis data secara deskripsif. Hasil penelitian adalah (1) hasil perikanan laut tangkap dan perikanan budidaya tambak Kabupaten Pati selama kurun waktu 5 tahun terakhir (2008-2012) menunjukkan tren positif yaitu terus mengalami peningkatan; (2) nilai persentase kontribusi perikanan budidaya tambak diatas 20\% (kisaran 23-28\%), sedangkan perikanan laut tangkap berada dibawah 20\% (kisaran 15-18\%); (3) hasil perikanan laut tangkap Kabupaten Pati pada tahun 2008 dan 2009 menduduki peringkat ketiga, tetapi 3 tahun selanjutnya yaitu tahun 2010, 2011 dan 2012 berhasil menduduki peringkat kedua dalam skala Provinsi Jawa tengah. Sedangkan perikanan budidaya tambak, Kabupaten Pati menempati peringkat kedua dalam 5 tahun terakhir.
\end{abstract}

Kata kunci: komoditas unggulan, perikanan budidaya tambak, perikanan laut tangkap 


\section{PENDAHULUAN}

Kabupaten Pati merupakan salah satu daerah di Provinsi Jawa Tengah yang berbatasan langsung dengan lautan yaitu Laut Jawa. Hal ini menjadikan Kabupaten Pati memiliki wilayah pesisir dan wilayah laut. Potensi yang dapat digali dan dimanfaatkan dari keberadaan wilayah pesisir dan laut ini salah satunya kegiatan yang berhubungan dengan perikanan, baik dalam bentuk perikanan laut dan perikanan budidaya.

Untuk Kabupaten Pati sendiri, kegiatan yang berhubungan dengan perikanan digolongkan ke dalam sektor pertanian. Berdasarkan data BPS Kab. Pati tahun 2012, subsektor perikanan menyumbang $5,12 \%$ dari $35,92 \%$ sumbangan sektor pertanian terhadap Produk Domestik Regional Bruto (PDRB) Kabupaten Pati. Dengan sumbangan tersebut, subsektor perikanan menjadi penyumbang terbesar kedua setelah subsektor tanaman bahan makanan untuk sektor pertanian. Dengan demikian, subsektor ini memiliki peran yang cukup besar terhadap pemasukan daerah di Kabupaten Pati.

Komoditas yang dicakup dalam subsektor perikanan adalah semua hasil kegiatan perikanan laut, perairan umum, tambak, kolam sawah, dan karamba (BPS Kab. Pati, 2012). Tetapi tidak semua jenis perikanan ini menjadi komoditas unggulan di Kabupaten Pati. Penelitian Damayanti (2013) menunjukkan bahwa jenis perikanan yang menjadi komoditas unggulan di Kabupaten Pati adalah komoditas perikanan budidaya tambak dan perikanan laut tangkap. Sedangkan untuk jenis perikanan perairan umum, kolam sawah, dan karamba belum menjadi komoditas unggulan di Kabupaten Pati.

Komoditas perikanan laut tangkap dan komoditas perikanan budidaya tambak tidak hanya dihasilkan oleh Kabupaten Pati. Selain Kabupaten Pati, dalam skala yang lebih besar yaitu ditingkat provinsi Jawa Tengah terdapat 16 kabupaten/kotamadya yang menghasilkan komoditas perikanan laut tangkap. Selain itu juga terdapat 16 kabupaten/kotamadya yang menghasilkan komoditas perikanan budidaya tambak (BPS Prov. Jateng, 2013).

Berdasarkan latar belakang tersebut, maka tujuan penelitian ini yaitu (1) menggambarkan perkembangan hasil komoditas perikanan unggulan Kabupaten Pati tahun 2008-2012; (2) menggambarkan besaran kontribusi komoditas perikanan unggulan Kabupaten Pati kepada Provinsi Jawa Tengah; dan (3) menggambarkan posisi komoditas perikanan unggulan Kabupaten Pati dalam skala Provinsi Jawa Tengah.

\section{TINJAUAN PUSTAKA}

\section{Perikanan}

Perikanan adalah semua kegiatan yang berhubungan dengan pengelolaan dan pemanfaatan sumber daya ikan dan lingkungan mulai dari praproduksi, produksi, pengolahan sampai dengan pemasaran yang dilaksanakan dalam suatu sistem bisnis perikanan (Perda Kab. Pati No. 19 Tahun 2009).

\section{Perikanan Laut Tangkap}

Perikanan laut tangkap diusahakan dengan cara melakukan penangkapan ikan. Jenis ikan laut yang ditangkap di Kabupaten Pati diantaranya adalah Layang, Lemuru, Ekor Kuning, Mata Besar, Kuniran dan Kapasan (BPS Kab. Pati, 2012).

\section{Perikanan Budidaya Tambak}

Tambak adalah kolam buatan, biasanya di daerah pantai yang diisi air dan dimanfaatkan sebagai sarana budidaya perairan (akuakultur). Penyebutan "tambak" ini biasanya dihubungkan 
dengan air payau atau air laut (Minawati, 2013).

BPS dalam Widowati (2004) mengartikan tambak sebagi lahan yang digunakan untuk melakukan pemeliharaan ikan, udang, fauna atau biota lainnya. Terletak tidak jauh dari laut dan air asin atau payau, merupakan campuran antara air laut dan air tawar.

\section{METODE PENELITIAN}

Penelitian ini menggunakan metode deskriptif dan dilaksanakan pada bulan Desember 2013. Sumber data berupa data sekunder. Data sekunder diperoleh dari dokumen relevan yaitu data produksi perikanan laut tangkap dan produksi perikanan budidaya tambak yang dikeluarkan oleh Badan Pusat Statistik Provinsi Jawa Tengah untuk tahun 2008, 2009, 2010, 2011 dan 2012.

Analisis data menggunakan analisis deskriptif yaitu dengan menggambarkan produksi perikanan laut tangkap dan perikanan budidaya tambak di Kabupaten Pati selama kurun waktu 5 tahun (tahun
2008, 2009, 2010, 2011 dan 2012) dan menghitung besar kontribusi Kabupaten Pati terhadap Provinsi Jawa Tengah. Kemudian hasil produksi perikanan laut tangkap dan perikanan budidaya tambak Kabupaten Pati dibandingkan dengan hasil produksi kabupaten/kotamadya di Provinsi Jawa Tengah. Hal ini untuk mengetahui posisi Kabupaten Pati dalam skala Provinsi.

\section{HASIL DAN PEMBAHASAN}

\section{Komoditas Perikanan Laut Tangkap Kabupaten Pati}

Komoditas perikanan laut tangkap ini merupakan komoditas unggulan kedua di Kabupaten Pati setelah komoditas perikanan budidaya tambak. Hasil produksi perikanan laut tangkap Kabupaten Pati selama kurun waktu 5 tahun terakhir (tahun 2008-2012) disajikan pada Gambar 1 dan perbandingan hasil perikanan laut tangkap Kabupaten Pati dengan total hasil perikanan laut tangkap di Provinsi Jawa Tengah disajikan pada Tabel 1.

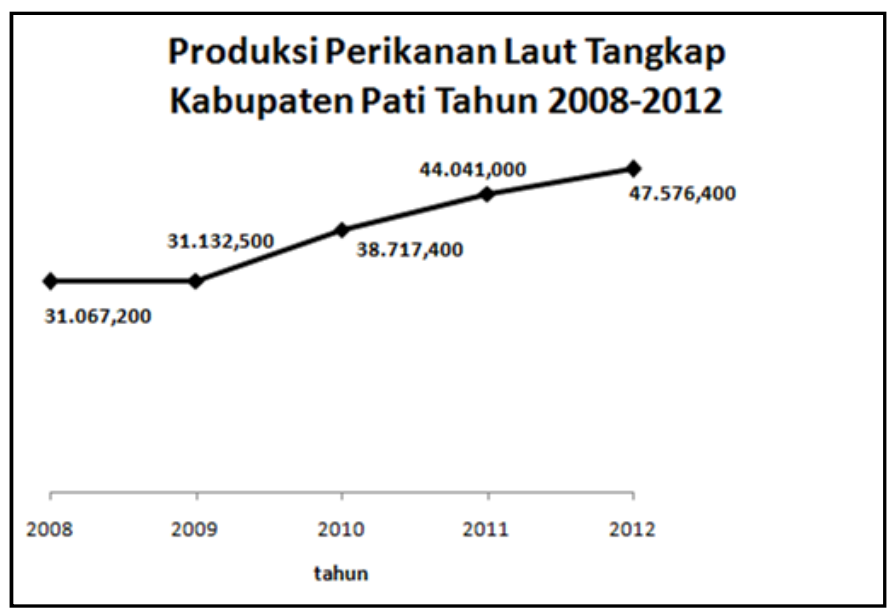

Gambar 1.

Produksi Perikanan Laut Tangkap Kabupaten Pati

Hasil perikanan laut tangkap Peningkatan hasil perikanan laut tangkap Kabupaten Pati selama kurun waktu 5 dari tahun 2008 ke tahun 2009 sebesar tahun terakhir menunjukkan tren positif, 65,300 ton. Tahun 2009 ke tahun 2010 yaitu terus mengalami peningkatan. meningkat sebesar 7.584,900 ton. 
Peningkatan sebesar 5.323,600 ton terjadi dari tahun 2010 ke tahun 2011. Sedangkan peningkatan sebesar $3.535,400$ ton terjadi pada tahun 2011 ke tahun 2012. Selama kurun waktu 5 tahun terakhir yaitu tahun
2008-2012 peningkatan hasil perikanan laut tangkap tertinggi terjadi pada tahun 2010, sedangkan peningkatan hasil periknan laut tangkap terendah terjadi pada tahun 2009.

Tabel 1.

Produksi Perikanan Laut Tangkap Kabupaten Pati

\begin{tabular}{ccccc}
\hline No & Tahun & Jateng & Pati & Persentase (\%) \\
\hline 1 & 2008 & $174.587,900$ & $31.067,200$ & 17,795 \\
2 & 2009 & $195.635,700$ & $31.132,500$ & 15,914 \\
3 & 2010 & $212.635,100$ & $38.717,400$ & 18,208 \\
4 & 2011 & $251.520,800$ & $44.041,000$ & 17,510 \\
5 & 2012 & $256.093,000$ & $47.576,400$ & 18,578 \\
\hline
\end{tabular}

Sumber : Pengolahan Data (2013)

Perikanan laut tangkap Kabupaten Pati pada tahun 2008 menyumbang $17,795 \%$ terhadap total hasil perikanan laut tangkap Provinsi Jawa Tengah. Untuk tahun 2009, besar sumbangan hasil perikanan laut tangkap Kabupaten Pati mengalami penurunan sebesar $1,881 \%$ menjadi $15,914 \%$. Jika dilihat dari hasil perikanan laut tangkap dalam skala Provinsi Jawa Tengah, sebenarnya hasil perikanan ini mengalami peningkatan dibandingkan tahun sebelumnya (tahun 2008). Hasil perikanan laut tangkap Kabupaten Pati sendiri pada tahun 2009 mengalami peningkatan, tetapi kontribusi Kabupaten Pati justru mengalami penurunan. Hal ini disebabkan karena kontribusi daerah lain di Provinsi Jawa Tengah yang menyumbang hasil perikanan laut tangkap lebih besar dibandingkan Kabupaten Pati.

Tahun 2010, kontribusi Kabupaten Pati mengalami peningkatan yang cukup besar yaitu sebesar 2,295\% sehingga besaran sumbangan Kabupaten Pati menjadi $18,208 \%$. Peningkatan kontribusi ini disebabkan hasil perikanan laut tangkap Kabupaten Pati pada tahun 2010 mengalami peningkatan tajam sehingga sumbangsih kepada Provinsi juga mengalami peningkatan. Untuk tahun 2011, besar kontribusi hasil perikanan laut tangkap Kabupaten Pati kembali mengalami penurunan sebesar 0,698\% menjadi $17,510 \%$. Kejadian pada tahun 2011 ini sama dengan yang terjadi pada tahun 2009, yaitu hasil perikanan laut tangkap mengalami peningkatan tetapi besar kontribusi justru mengalami penurunan. Sama dengan tahun 2009, hal yang menjadi pemicu adalah hasil produksi daerah lain yang mengalami peningkatan lebih besar dibandingkan yang dialami Kabupaten Pati. Sedangkan untuk tahun 2012, kontribusi kembali meningkat sebesar $1,068 \%$ menjadi $18,578 \%$. Hal ini karena hasil produksi mengalami kembali peningkatan sehingga berimbas pada besaran kontribusi yang juga meningkat. Secara garis besar, kontribusi perikanan laut tangkap Kabupaten Pati kepada Provinsi Jawa Tengah selama kurun waktu 5 tahun terakhir (2008-2012) berada pada kisaran $15-18 \%$.

\section{Komoditas Perikanan Budidaya Tambak Kabupaten Pati}

Komoditas perikanan unggulan pertama di Kabupaten Pati adalah komoditas perikanan budidaya tambak. 
Hasil produksi perikanan budidaya tambak Kabupaten Pati selama kurun waktu 5 tahun terakhir (2008-2012) disajikan pada Gambar 2. Untuk perbandingan hasil perikanan budidaya tambak Kabupaten Pati dengan total hasil perikanan budidaya tambak di Provinsi Jawa Tengah disajikan pada Tabel 2.

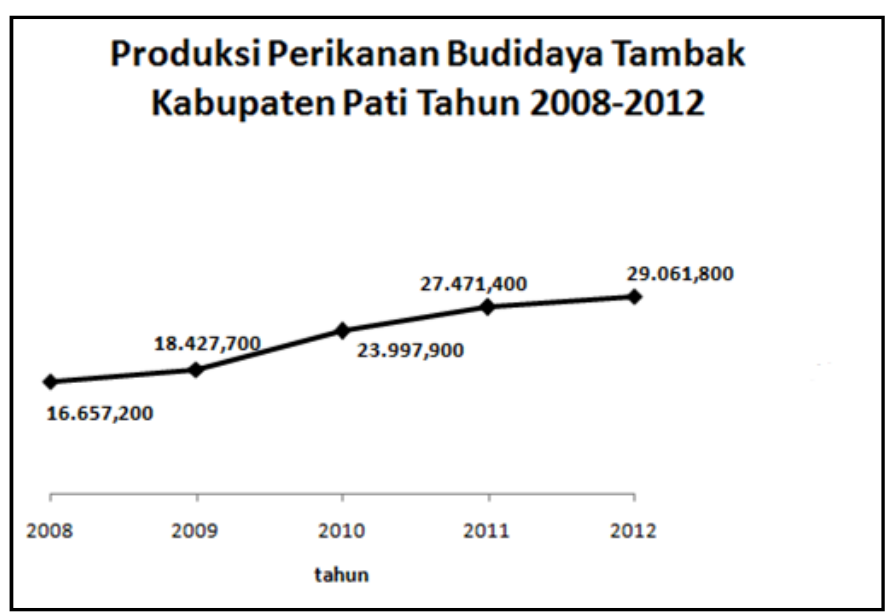

Gambar 2.

Produksi Perikanan Budidaya Tambak Kabupaten Pati

Sama halnya dengan hasil perikanan laut tangkap, hasil perikanan budidaya tambak Kabupaten Pati selama kurun waktu 5 tahun terakhir juga menunjukkan tren yang positif dengan terus mengalami peningkatan. Pada tahun 2008 adalah 16.657,200 ton. Pada tahun 2009 hasil produksi meningkat $1.770,500$ ton menjadi $18.427,700$ ton. Tahun 2010 mengalami peningkatan yang cukup tajam sebesar $5.570,200$ ton menjadi $23.997,900$ ton. Tahun 2011 produksi kembali mengalami peningkatan sebesar 3.473,500 ton menjadi $27.471,400$ ton dan tahun 2012 juga meningkat $1.590,400$ ton menjadi $29.061,800$ ton. Dalam kurun waktu 2008-2012, peningkatan produksi perikanan budidaya tambak tertinggi terjadi pada tahun 2010 dan peningkatan produksi terendah terjadi pada tahun 2012. Produk perikanan budidaya tambak Kabupaten Pati (tanpa membedakan jenis ikan budidaya) terus mengalami peningkatan setiap tahunnya.

Tabel 2.

Produksi Perikanan Budidaya Tambak Kabupaten Pati

\begin{tabular}{ccrcc}
\hline No & Tahun & \multicolumn{1}{c}{ Jateng } & Pati & Persentase (\%) \\
\hline 1 & 2008 & $68.395,800$ & $16.657,200$ & 24,354 \\
2 & 2009 & $73.033,000$ & $18.427,700$ & 25,232 \\
3 & 2010 & $84.807,400$ & $23.997,900$ & 28,297 \\
4 & 2011 & $115.786,500$ & $27.471,400$ & 23,726 \\
5 & 2012 & $109.303,300$ & $29.061,800$ & 26,588 \\
\hline
\end{tabular}

Sumber : Pengolahan Data (2013) 
Besar kontribusi perikanan budidaya tambak Kabupaten Pati kepada Provinsi Jawa Tengah pada tahun 2008 adalah 24,354\%. Pada tahun 2009, besaran kontribusi ini mengalami peningkatan sebesar $0,878 \%$ menjadi $25,232 \%$. Tahun 2010 kontribusi perikanan budidaya tambak ini kembali meningkat 3,065\% menjadi 28,297\%. Peningkatan yang terjadi selaras dengan jumlah produksi yang terus mengalami peningkatan. Hal sebaliknya terjadi pada tahun 2011. Walaupun hasil produksi mengalami peningkatan, tetapi besar sumbangan kepada Provinsi justru mengalami penurunan yaitu sebesar $4,571 \%$ dari yang semula 28,297\% menjadi $23,726 \%$. Faktor jumlah peningkatan produksi yang lebih kecil dibanding daerah lain di Provinsi Jawa Tengah diduga menjadi penyebab menurunnya persentase kontribusi hasil perikanan budidaya tambak Kabupaten Pati dalam skala provinsi ini.

Kemudian untuk tahun 2012, jumlah produksi yang juga terus meningkat menjadikan kontribusi Kabupaten Pati kembali naik. terjadi peningkatan sebesar $2,862 \%$ sehingga menjadi $26,588 \%$. Besaran persentase kontribusi ini sangat dipengaruhi oleh jumlah produksi daerah lain. Jika daerah lain mengalami peningkatan yang cukup signifikan, maka persentase Kabupaten Pati akan mengalami penurunan. Secara garis besar, kontribusi perikanan budidaya tambak
Kabupaten Pati kepada Provinsi Jawa Tengah berada pada kisaran 23-28\%.

Nilai persentase kontribusi perikanan budidaya tambak lebih besar dibandingkan kontribusi perikanan laut tangkap. Perikanan budidaya tambak selama kurun waktu 5 tahun terakhir menunjukkan kontribusi diatas $20 \%$, sedangkan perikanan laut tangkap berada dibawah 20\%. Namun jika dilihat dari jumlah produksi, perikanan laut tangkap justru menghasilkan produk yang jauh lebih besar dibandingkan perikanan budidaya tambak. Walaupun demikian, persentase kontribusi perikanan laut tangkap Kabupaten Pati dalam skala Provinsi Jawa Tengah tetap lebih kecil dibandingkan perikanan budidaya tambak. Hal ini sangat terkait dengan jumlah produksi daerah lain di Jawa Tengah yang mempengaruhi jumlah keseluruhan produksi perikanan baik laut tangkap maupun budidaya tambak di Provinsi Jawa Tengah.

\section{Komoditas Perikanan Laut Tangkap Tingkat Provinsi Jawa Tengah}

Hasil perikanan laut tangkap Provinsi Jawa Tengah dihitung dari kabupaten/kotamadya di Provinsi Jawa Tengah yang menghasilkan produk perikanan laut tangkap.

Kabupaten/kotamadya penghasil perikanan laut tangkap di Provinsi Jawa Tengah disajikan pada Tabel 3. 
Tabel 3.

Kabupaten Dan Kota Penghasil Perikanan Laut Tangkap Di Provinsi Jawa Tengah

\begin{tabular}{rlrrrrr}
\hline \multirow{2}{*}{ No } & Kabupaten/Kota & \multicolumn{5}{c}{ Perikanan Laut Tangkap (ton) } \\
\cline { 3 - 7 } & & \multicolumn{1}{c}{2008} & \multicolumn{1}{c}{2009} & \multicolumn{1}{c}{2010} & \multicolumn{1}{c}{2011} & \multicolumn{1}{c}{2012} \\
\hline 1 & Kab. Cilacap & $8.509,500$ & $14.667,400$ & $4.832,700$ & $19.921,400$ & $22.963,100$ \\
2 & Kab. Kebumen & $2.247,500$ & $2.249,400$ & 600,900 & $3.741,800$ & $3.692,900$ \\
3 & Kab. Purworejo & 53,700 & 67,400 & 77,100 & 61,300 & 68,200 \\
4 & Kab. Wonogiri & 21,200 & 24,300 & 24,700 & 54,900 & 58,700 \\
5 & Kab. Rembang & $32.372,100$ & $40.449,100$ & $40.566,600$ & $56.730,700$ & $64.941,700$ \\
6 & Kab. Pati & $31.067,200$ & $31.132,500$ & $38.717,400$ & $44.041,000$ & $47.576,400$ \\
7 & Kab. Jepara & $5.940,000$ & $5.992,600$ & $6.906,400$ & $7.222,800$ & $6.429,200$ \\
8 & Kab. Demak & $1.809,700$ & $1.903,900$ & $1.758,300$ & $3.133,600$ & $3.749,700$ \\
9 & Kota Semarang & 164,100 & 175,100 & 335,700 & 567,900 & $2.031,800$ \\
10 & Kab. Kendal & $1.312,000$ & $1.530,800$ & $1.550,500$ & $1.834,600$ & $29.847,600$ \\
11 & Kab. Batang & $22.853,600$ & $23.296,200$ & $29.931,600$ & $31.244,200$ & $2.128,100$ \\
12 & Kab. Pekalongan & $1.714,600$ & $1.764,100$ & $1.974,000$ & $2.059,800$ & $18.126,000$ \\
13 & kota Pekalongan & $31.948,700$ & $33.045,300$ & $35.678,600$ & $19.355,700$ & $1.432,200$ \\
14 & Kab. Pemalang & $10.791,500$ & $11.014,400$ & $14.064,600$ & $17.107,800$ & $4.442,500$ \\
15 & Kab. Tegal & 434,700 & 588,100 & 415,100 & $1.269,800$ & 856,700 \\
16 & Kota Tegal & $20.961,500$ & $25.231,300$ & $29.226,400$ & $35.206,300$ & $19.559,000$ \\
17 & Kab. Brebes & $2.386,300$ & $2.503,800$ & $5.974,500$ & $7.967,400$ & $28.189,300$ \\
\hline Sunyyyyy
\end{tabular}

Sumber: BPS Prov. Jateng (2009, 2010, 2011, 2012 dan 2013)

Tabel 3 menunjukkan hasil produksi perikanan laut tangkap dari 14 kabupaten dan 3 kotamadya di Provinsi Jawa Tengah selama 5 tahun terakhir. Daerah yang mengalami peningkatan produksi dari tahun ke tahun (tahun 2008-2012) adalah Wonogiri, Rembang, Pati, Kota Semarang, Kendal, Pekalongan dan Brebes. Sedangkan 10 daerah lain yang mengalami produksi perikanan laut tangkap yang fluktuatif yaitu Cilacap, Kebumen, Purworejo, Jepara, Demak, Batang, Kota Pekalongan, Pemalang, Tegal dan Kota
Tegal. Bahkan pada tahun 2012 beberapa daerah diantaranya justru mengalami penurunan produksi yaitu Kebumen, Jepara, Batang, Pekalongan, Pemalang, Tegal dan Kota Tegal.

Untuk Kabupaten Pati sendiri dalam kurun waktu 5 tahun terakhir selalu menempati urutan 3 besar sebagai daerah penghasil perikanan laut tangkap di Provinsi Jawa Tengah. Urutan 3 besar penghasil perikanan laut tangkap di provinsi Jawa Tengah disajikan pada Gambar 3. 


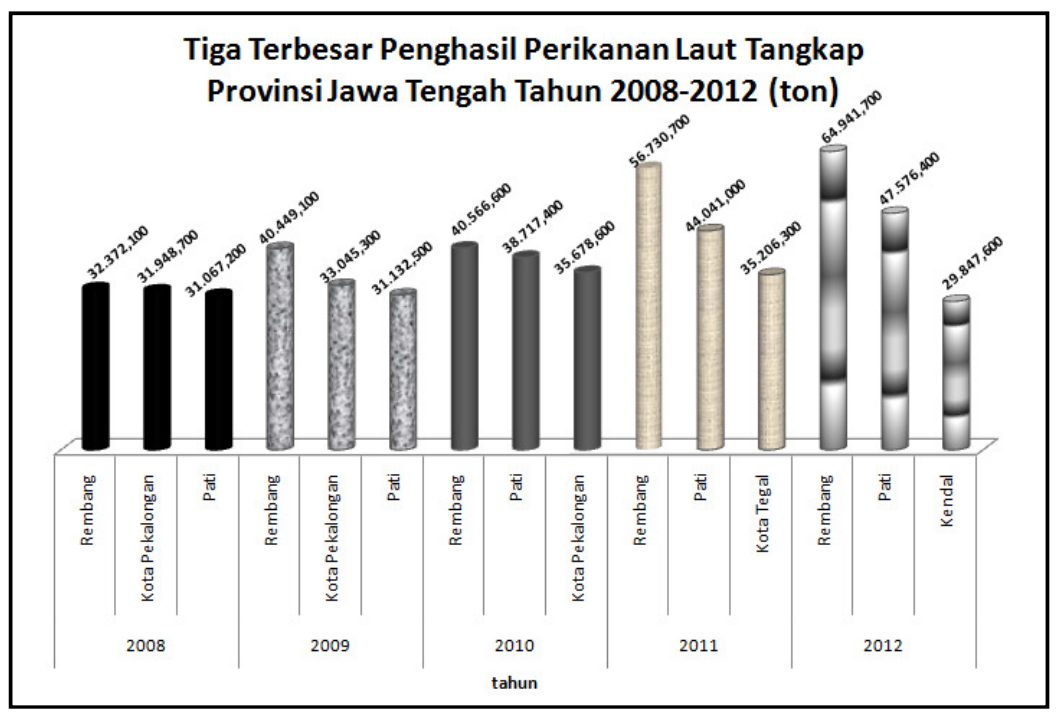

Gambar 3.

Produksi Perikanan Laut Tangkap Tingkat Provinsi Jawa Tengah

Kabupaten Pati pada tahun 2008 dan 2009 menduduki peringkat ketiga, tetapi 3 tahun selanjutnya yaitu tahun 2010, 2011 dan 2012 berhasil menduduki peringkat kedua dalam skala Provinsi Jawa Tengah untuk hasil perikanan laut tangkapnya. Peringkat pertama sejak tahun 2008 sampai tahun 2012 selalu ditempati oleh Kabupaten Rembang. Sedangkan peringkat ketiga selama 3 tahun yaitu tahun 2008, 2009 dan 2010 ditempati oleh Kota Pekalongan. Tahun 2011 peringkat ketiga ditempati oleh Kota Tegal dan tahun 2012 ditempati Kabupaten Kendal.

Produksi perikanan laut tangkap Kabupaten Pati dalam kurun waktu 5 tahun terakhir tidak berkembang secara pesat. Peningkatan produksi perikanan laut tangkapnya tidak sebesar daerah tetangganya yaitu Kabupaten Rembang. Kabupaten Pati memiliki 8 Tempat Pelelangan Ikan (TPI) yang menjadi tempat pendaratan dan transaksi lelang maupun jual beli hasil perikanan laut tangkap. Dari segi luas wilayah laut, Kabupaten Pati memiliki panjang garis pantai $\pm 60 \mathrm{~km}$ (Damayanti, 2011). Dalam UU No. 32 Tahun 2004 Pasal 18 disebutkan bahwa kewenangan untuk mengelola sumber daya di wilayah laut paling jauh 12 (dua belas) mil laut diukur dari garis pantai ke arah laut lepas dan/atau ke arah perairan kepulauan untuk provinsi dan $1 / 3$ (sepertiga) dari wilayah kewenangan provinsi untuk kabupaten/kota. Jika mengacu pada aturan tersebut, dapat dikatakan bahwa Kabupaten Pati memiliki wilayah laut \pm 180 mil laut. Dengan potensi wilayah laut ini, hasil perikanan laut tangkap Kabupaten Pati sangat mungkin untuk lebih dikembangkan dengan mengoptimalkan penggunaan teknologi dan peralatan penangkapan yang lebih mutakhir.

\section{Komoditas Perikanan Budidaya Tambak Tingkat Provinsi Jawa Tengah}

Hasil perikanan budidaya tambak Provinsi Jawa Tengah dihitung dari kabupaten/kotamadya di Provinsi Jawa Tengah yang menghasilkan produk perikanan budidaya tambak. Kabupaten/kotamadya penghasil perikanan budidaya tambak di Provinsi Jawa Tengah disajikan pada Tabel 4. 
Tabel 4.

Kabupaten dan Kota Penghasil Perikanan Budidaya Tambak Di Provinsi Jawa Tengah

\begin{tabular}{rlrrrrr}
\hline \multirow{2}{*}{ No } & \multirow{2}{*}{ Kabupaten/Kota } & \multicolumn{5}{c}{ Perikanan Budidaya Tambak (ton) } \\
\cline { 3 - 7 } & & \multicolumn{1}{c}{2008} & \multicolumn{1}{c}{2009} & \multicolumn{1}{c}{2010} & \multicolumn{1}{c}{2012} \\
\hline 1 & Kab. Cilacap & 740,900 & 629,100 & 879,100 & $1.073,000$ & $1.106,100$ \\
2 & Kab. Kebumen & 2,900 & 5,700 & 5,400 & 11,800 & 13,500 \\
3 & Kab. Purworejo & 261,300 & 269,600 & 281,500 & 293,200 & 277,000 \\
4 & Kab. Rembang & 411,900 & 432,300 & 862,700 & $1.080,400$ & $1.092,000$ \\
5 & Kab. Pati & $16.657,200$ & $18.427,700$ & $23.997,900$ & $27.471,400$ & $29.061,800$ \\
6 & Kab. Kudus & 50,200 & - & 20,000 & - & - \\
7 & Kab. Jepara & $1.989,200$ & $2.240,200$ & $2.490,700$ & $4.026,300$ & $3.747,600$ \\
8 & Kab. Demak & $8.030,500$ & $9.383,500$ & $8.343,100$ & $9.499,200$ & $9.001,100$ \\
9 & Kota Semarang & 447,200 & 149,600 & 393,000 & $1.668,800$ & $1.573,200$ \\
10 & Kab. Kendal & $6.671,800$ & $7.419,100$ & $6.452,000$ & $8.141,500$ & $7.373,200$ \\
11 & Kab. Batang & 380,600 & 509,300 & $1.102,500$ & 771,100 & 911,500 \\
12 & Kab. Pekalongan & $1.061,100$ & $1.128,700$ & $2.896,900$ & $3.964,900$ & $3.663,500$ \\
13 & kota Pekalongan & 194,200 & 143,900 & 555,400 & 786,700 & 781,200 \\
14 & Kab. Pemalang & $3.035,700$ & $3.129,800$ & $3.654,800$ & $5.772,300$ & $4.795,100$ \\
15 & Kab. Tegal & 368,700 & 198,000 & 234,200 & 247,500 & 178,600 \\
16 & Kota Tegal & 174,700 & 178,000 & 207,700 & 243,000 & 657,400 \\
17 & Kab. Brebes & $27.917,700$ & $28.788,600$ & $32.430,500$ & $50.735,400$ & $45.070,600$ \\
\hline
\end{tabular}

Sumber : BPS Prov. Jateng (2009, 2010, 2011, 2012 dan 2013)

Hasil produksi perikanan budidaya tambak Provinsi Jawa Tengah selama 5 tahun terakhir berasal dari 14 kabupaten dan 3 kotamadya. Daerah yang mengalami peningkatan produksi dari tahun 2008 sampai tahun 2012 adalah Rembang, Pati dan Kota Tegal.

Daerah yang mengalami produksi perikanan budidaya tambak fluktuatif yaitu Cilacap, Kebumen, Purworejo, Kudus, Jepara, Demak, Kota Semarang, Kendal, Batang, Pekalongan, Kota Pekalongan, Pemalang, Tegal dan Brebes. Bahkan terdapat 12 daerah yang pada tahun 2012 justru mengalami penurunan produksi yaitu Cilacap, Purworejo, Kudus, Jepara, Demak, Kota Semarang, Kendal, Batang, Pekalongan, Kota Pekalongan, Pemalang, Tegal dan Brebes.

Sama halnya dengan perikanan laut tangkap, perikanan budidaya tambak Kabupaten Pati selama kurun waktu 5 tahun terakhir selalu menempati urutan 3 besar. Urutan 3 besar penghasil perikanan budidaya tambak di provinsi Jawa Tengah disajikan pada Gambar 4. 


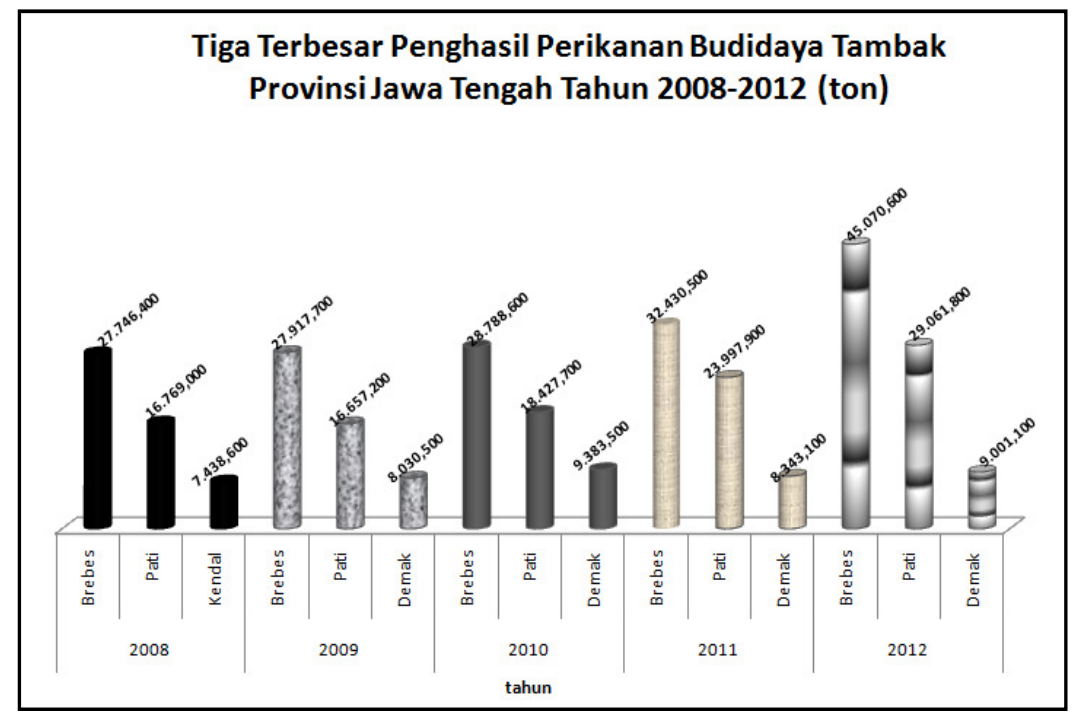

Gambar 4.

Produksi Perikanan Budidaya Tambak Tingkat Provinsi Jawa Tengah

Kabupaten Brebes merupakan penghasil perikanan budidaya tambak terbesar di Provinsi Jawa Tengah dalam kurun waktu 2008 sampai 2012. Untuk peringkat kedua terbesar (5 tahun terakhir) ditempati oleh Kabupaten Pati. Peringkat ketiga tahun 2008 ditempati oleh Kabupaten Kendal dan tahun2009-2012 posisi ini diambil oleh Kabupaten Demak.

Perkembangan produksi perikanan budidaya tambak Kabupaten Pati dalam 5 tahun terakhir tidak berjalan secara pesat, tetapi menunjukkan kecenderungan terus mengalami peningkatan. Potensi tambak Kabupaten Pati terbesar di 7 kecamatan Batangan, Juwana, Wedarijaksa, Trangkil, Margoyoso, Tayu dan Dukuhseti (BPS Kab. Pati, 2013) atau sebanyak 54 desa pesisir (Bappeda dan IPB, 2001). Luas area pertambakan Kabupaten Pati pada tahun 2012 mencapai 6,88\% (10.346 Ha) dari luas wilayah Kabupaten Pati secara keseluruhan (BPS Kab. Pati, 2013). Dengan luas lahan tambak tersebut, hasil perikanan budidaya tambak Kabupaten Pati sangat mungkin untuk lebih dikembangkan lagi dengan mengoptimalkan penggunaan lahan tambak untuk budidaya ikan. Selain itu, beberapa kendala yang masih dihadapi petambak harus segera dicari solusi pemecahannya. Kendala tersebut antara lain, harga pakan yang tinggi, harga jatuh saat panen raya dan budidaya udang sering merugi (Kanlitbang Kab. Pati, 2011).

\section{KESIMPULAN DAN SARAN}

\section{Kesimpulan}

1. Hasil perikanan laut tangkap dan perikanan budidaya tambak Kabupaten Pati selama 5 tahun terakhir (20082012) menunjukkan tren positif yaitu terus mengalami peningkatan.

2. Nilai persentase kontribusi perikanan budidaya tambak lebih besar dibandingkan kontribusi perikanan laut tangkap. Perikanan budidaya tambak selama 5 tahun terakhir berada diatas $20 \%$ (kisaran 23-28\%), sedangkan perikanan laut tangkap berada dibawah 20\% (kisaran 15-18\%).

3. Hasil perikanan laut tangkap Kabupaten Pati tahun 2008 dan 2009 menduduki peringkat ketiga, tetapi 3 tahun selanjutnya (2010, 2011 dan 2012) berhasil menduduki peringkat kedua dalam skala Provinsi Jawa tengah. 
Sedangkan perikanan budidaya tambak, Kabupaten Pati menempati peringkat kedua dalam 5 tahun terakhir.

\section{Saran}

Dengan pertimbangan bahwa komoditas perikanan budidaya tambak berproduksi lebih besar dibandingkan komoditas perikanan laut tangkap, maka bagi Dinas Kelautan dan Perikanan Kabupaten Pati perlu menggalakkan kegiatan perikanan budidaya tambak dengan berbagai bentuk bantuan pemodalan, penyuluhan, pelatihan dan aplikasi teknologi modern untuk memacu produksi.

\section{DAFTAR PUSTAKA}

Badan Pusat Statistik Kabupaten Pati. 2013. Pati Dalam Angka Tahun 2012. Pati.

Badan Pusat Statistik Kabupaten Pati. 2013. Produk Domestik Regional Bruto Kabupaten Pati Tahun 2012. Pati.

Damayanti, H. O. 2013. Komoditas Perikanan Di Kabupaten Pati. Jurnal Litbang IX (2): 98-106.

Peraturan Daerah Kabupaten Pati Nomor 19 Tahun 2009 Tentang Tempat Pelelangan Ikan.

Minawati, L. F. 2013. Budidaya Ikan Air Tawar di Desa Selajambe Kecamatan Cisaat Kabupaten Sukabumi. Skripsi. Jurusan Pendidikan Geografi FPIPS. Bandung : Universitas Pendidikan

Widowati, L. L. 2004. Analisis Kesesuaian Perairan Tambak Di Kabupaten Demak Ditinjau Dari Aspek Produktivitas Primer Menggunakan Penginderaan Jauh. Tesis. Program Studi Magister Manajemen Sumberdaya Pantai. Semarang : Universitas Diponegoro
Badan Pusat Statistik Provinsi Jawa Tengah. 2009. Jawa Tengah Dalam Angka 2008. Semarang.

Badan Pusat Statistik Provinsi Jawa Tengah. 2010. Jawa Tengah Dalam Angka 2009. Semarang.

Badan Pusat Statistik Provinsi Jawa Tengah. 2011. Jawa Tengah Dalam Angka 2010. Semarang.

Badan Pusat Statistik Provinsi Jawa Tengah. 2012. Jawa Tengah Dalam Angka 2011. Semarang.

Badan Pusat Statistik Provinsi Jawa Tengah. 2013. Jawa Tengah Dalam Angka 2012. Semarang.

Damayanti, H. O. 2011. Kajian Model Hidrodinamika Dengan Menggunakan Data Constant Dan Transient. Jurnal Litbang. Vol VII (1): 23-31.

Undang-undang Republik Indonesia Nomor 32 Tahun 2004 Tentang Pemerintah Daerah.

Bappeda Kabupaten Pati dan Institut Pertanian Bandung. 2001. Album Peta Pemetaan Potensi Sumberdaya Pesisir Dan Laut Wilayah Kabupaten Pati. Pati.

Kantor Penelitian dan Pengembangan Kabupaten Pati. 2011. Revitalisasi Kawasan Pesisir. Laporan Penelitian. Kantor Penelitian dan Pengembangan Kabupaten Pati. Pati.

\section{BIODATA PENULIS}

Herna Octivia Damayanti, lahir 6 Oktober 1985 di kota Kudus Jawa Tengah. Pendidikan S1 Program Studi Oseanografi Jurusan Ilmu Kelautan Fakultas Perikanan dan Ilmu Kelautan Universitas Diponegoro tahun 2009. Saat ini bekerja sebagai Peneliti di Kantor Penelitian dan Pengembangan Kabupaten Pati. 